Bartın Üniversitesi

Eğitim Fakültesi Dergisi

Cilt 6, Sayı 2, s. 715-736, Haziran 2017 BARTIN - TÜRKIYE

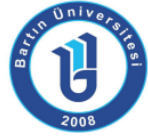

ISSN: 1308-7177

\title{
Fen Bilgisi Öğretmen Adaylarının Bilim-Teknoloji-Toplum Hakkındaki Görüşlerine Bilim Kurgu Filmlerin Etkisi
}

\author{
Fatma ÖNEN ÖZTÜRK, Marmara Üniversitesi Atatürk Eğitim Fakültesi, fatma_onen@hotmail.com
}

Özet: Araştırmanın amacı; bilim kurgu filmlerin, fen bilgisi öğretmen adaylarının bilim-teknolojitoplum hakkındaki görüşlerine olan etkisinin belirlenmesidir. Araştırma durum çalışmasına uygun olarak tasarlanmış olup; 2012-2013 öğretim yılı bahar döneminde, İstanbul'da bulunan bir üniversitenin ilköğretim bölümü fen bilgisi öğretmenliği $A B D$ ikinci sınıfında öğrenim görmekte olan 20 öğretmen adayı ile gerçekleştirilmiştir. Araştırma 5 hafta sürmüş ve bu süreçte bilim kurgu temelli 10 film izlenmiştir. Araştırmadan elde edilen sonuçlar öğretmen adaylarının bilim-teknoloji-toplum hakkındaki görüşlerinin uygulama öncesi ve sonrasında doğru ve yeterli niteliklere sahip olduğunu ortaya koymaktadır. Bu sonucun yanı sıra; uygulama sonrasında öğretmen adaylarının görüşlerinin nicelik ve nitelik bakımından farklı görüşleri de içerdiği görülmektedir. Bu bağlamda bilim kurgu filmlerin bilimteknoloji-toplum hakkındaki görüşlere yönelik katkısının, olumlu olduğu söylenebilir.

Anahtar sözcükler: Bilimkurgu film, fen eğitimi, öğretmen adayı, bilim, teknoloji, toplum

\section{The Impacts of Science Fiction Films on Prospective Science Teachers' Views about Science-Technology-Society}

\begin{abstract}
The purpose of the research is to determine the impacts of science fiction films on prospective science teachers' views about science-technology-society. Designed in accordance with case study, the research was conducted with 20 prospective science teachers studying at the second grade of primary science education department of a university in Istanbul during the spring term of 2012-2013 academic year. The research lasted for 5 weeks and 10 films based on science fiction were watched in this process. When the results obtained from the research are evaluated, it is revealed that the views of prospective teachers about the science-technology-society have both accurate and sufficient qualities before and after the application. In addition to this result, it was also determined that the opinions of the prospective teachers differed both quantitatively and qualitatively after the application. In this regard, it can be said that the influence of science fiction films on the views about science-technologysociety have contributed positively.
\end{abstract}

Key Words: Science fiction film, science education, prospective science teacher, science, technology, society 


\section{GiRiş}

Farklı reform hareketleriyle birlikte gerek fen gerekse diğer derslerin öğretim programlarında bilim ve bilimsel bilgiye verilen önem artmış, buna paralel olarak da klasik eğitim anlayışından uzaklaşılarak, bilim ve bilimsel bilginin önemi üzerine odaklanılmış ve bu süreçte de fen derslerinin önemi vurgulanmıştır. Türk Milli Eğitiminin temel amacı "millî birlik ve bütünlük içinde iktisadî, sosyal ve kültürel kalkınmayı desteklemek ve hızlandırmak; Türk milletini çağdaş uygarlığın yapıcı, yaratıcı, seçkin bir ortağı yapmak" olarak belirlenmiştir (MEB, 2006). Bu bağlamda Fen ve Teknoloji dersi programının vizyonu, "tüm öğrencileri fen okuryazarı bireyler olarak yetiştirmektir" olarak belirlenmiştir (MEB, 2013a). Çepni, Bacanak ve Küçük (2003) de fen eğitiminin temel amacının fen okuryazarı bireyler yetiştirilmesi olduğunu ve bu süreçte de fen-teknoloji-toplum eğitiminin öneminin yadsınamayacağını belirtmişlerdir.

Fen okuryazarlığı oldukça önemli bir kavram olmasına ve gerçekleştirilen reform hareketleriyle birlikte özellikle fen ve teknoloji dersi öğretim programında yer bulmasına karşın; öğrencilerin bu konudaki yeterliklerinin oldukça düşük olduğu görülmektedir. 2012 yılında gerçekleştirilen PISA sınav sonucunda Türkiye'nin fen okuryazarlı̆ı̆ında, en düşük düzeyde olan öğrenci oranının azaldığı; buna karşın elde edilen bu sonucun halen OECD ortalamasındaki öğrenci oranının oldukça üzerinde olduğu görülmektedir (MEB, 2013b). Elde edilen bu sonuç gerçekleştirilen yenilenme çabalarına karşın eğitim-öğretim sürecinde halen aksaklıkların olduğunu ve soruna farklı açılardan yaklaşıması gerektiğini de ortaya koyar niteliktedir. Sürmeli (2013) yeni Fen Bilimleri öğretim programının amacının, görsel ve popüler medyada yer alan yazıları, filmleri ve tartışmaları anlayabilen bireylerin yetiştirilmesi olduğunu belirtmektedir (Sürmeli, 2013'ten aktaran Seçkin Kapucu, 2014). Araştırmada da bu odak noktasından yola çıkılmış ve öğretmen adaylarının bilim-teknoloji-toplum hakkındaki görüşlerine etkisinin olacağı düşüncesinden hareketle, görsel medyadan faydalanılmıştır.

Fife (1999) öğrencilerin her gün daha da az okuduğunu ve okuma metinlerinden çok görsel sunumlardan hoşlandıklarını belirtmektedir. Acar (2003) da öğrencilerin bilimsel gerçekleri ve prensipleri ders içi kaynaklardan öğrendikleri kadar, ders dışı kaynaklardan da öğrendiğini ifade etmiştir. Shaw ve Dybdahl'a (2000) göre ders dışı kaynaklar görsel ve yazılı medya araçları olmak üzere ikiye ayrılmaktadır. Seçkin Kapucu'nun (2014) belirttiğine göre görsel medya, hangi boyutta olursa olsun bireyi etkilemekte ve eğitim sisteminin vazgeçilmez araçlarından biri durumuna gelmektedir. Görsel medya araçlarından biri olan filmler ise Akbaş'ın (2011) belirttiğine göre toplumsal yaşamın bir parçası haline gelmiş ve eğlence amacının yanı sıra eğitim ve bilimsel araştırma amacıyla da kullanılmaktadır. Kirby'de (2003) filmlerin yalnızca görsel bir teknoloji olmadığını, aynı zamanda da dünyanın basit bir sunumunu gerçekçi bir şekilde yaparak, bilimsel tartışmaların toplumsal versiyonunu oluşturduğunu ifade etmiştir. Filmlerin öğretim sürecindeki etkililiğinin en önemli sebeplerinden birisi, yeni neslin görsel medyaya oldukça aşina olmasıdır (Alvarez vd., 2004). Weber ve Silk (2007) de öğrencilerin ilgilerini çeken öğrenme yöntemlerini tercih ettiklerini ve filmlerin de bunlardan biri olduğunu belirtmektedir. Dark'ın (2005) belirttiğine göre filmler mevcut görüşleri öğrencilere çok hızlı bir şekilde ve kolaylıkla aktarmakta; bu bağlamda oldukça etkin bir "görsel öğrenme" yardımcısı olarak nitelenmektedir. Bu bağlamda farkıı türdeki filmlerden biri olan bilim kurgu filmlerin de öğretim sürecinde etkin olarak kullanılabilecek bir araç olduğu düşünülmektedir.

Bilim kurgu okuyucuyu eğlendirmeyi amaçlarken; hayal gücünü geliştirir, fene yönelik ilgiyi arttırır ve eğitirken tahminde bulundurmayı sağlar (Lundquist, 2012). Yazıcı ve Altıparmak (2010) bilim kurgu filmlerin, senaryoların ve hikâyelerin fen eğitiminde oldukça etkin olarak kullanılabilecek bir öğretim aracı olduğunu belirtmişlerdir. Ongel Erdal'ın vd. (2004) belirttiğine göre eğitimciler, bilimsel kavramlarla alan bilgisini ilişkilendirilebilmek için bilim kurgu 
hikâyeleri eğitimsel bir araç olarak kullanma üzerine odaklanmışlardır. Bilim kurguyla ilgili materyaller öğrencilerin dikkatini sınıf içerisinde gerçekleştirilen diğer aktivitelere oranla daha fazla çekmekte ve öğrenme seviyesini belirgin bir şekilde artırmakta; ayrıca öğrencilerin hayal güçlerini kullanmalarını, düşünmek ve tartışmak için fırsatlar yaratmalarını ve konuları hem teorik hem de deneysel bir şekilde öğrenmelerini sağlamaktadır (Yazıcı ve Altıparmak, 2010). Ayrıca pek çok eğitimciye göre bilim kurgu aktiviteler; bilim, sosyal ilişkiler, fantezi, popüler sanat, din ve benzeri farklı pek çok alanı içermesi nedenleriyle doğası gereği disiplinler arasıdır (Aquinc, 1976; Bixler, 2007).

Bilim kurgu filmler bilime yer vermesi, henüz var olmayan ancak gerçekleşebilecek bilim ve teknolojinin içeriğine ilişkin fikir sunması, olumlu ve olumsuz durumlara yönelik görüş ortaya koyması, bireyin hayal yeteneğine atıfta bulunması, sinemanın etkisini içermesi ve çevresel etmenler gibi farklı nedenler dolayısıyla dikkat çekici niteliktedir (Balbağ vd., 2012). Cavanaugh'a (1996) göre bilim kurgu filmler, fen kavramlarının görselleştirilmesini ve diğer disiplinlerle ilişkilendirilmesini sağlayarak öğrenmeye neden olmaktadır. Barnett ve Kafka (2007) da filmlerin mevcut bilimsel teoriyle doğrulanması halinde, bireyde kalıcı zihinsel imajlar oluşturabileceğini belirtmektedir. Dubeck'in vd. (1993) bilim kurgu filmleri kullanarak gerçekleştirdiği çalışmada öğrencilerin "fenin keşif" sürecini ve feni daha iyi anladıkları; ayrıca bilim kurgu filmlerin sözde bilimsel konuların belirlenmesine katkı sağladığı tespit edilmiştir. Sürmeli (2012) de bilim kurgu filmlerin hayal gücünü, problem çözme, yorumlama ve bilimsel süreç becerilerini, son olarak bilimsel okuryazarlığı geliştirdiğini belirtmişlerdir. Farklı literatür çalışmaları gerek hikaye gerekse film olsun bilim kurgu temelli öğretimin, öğrenme sürecindeki etkililiğini ortaya koymaktadır.

Uluslararası literatürde bilim kurgu temelli pek çok çalışma yer almasına karşın (Barnett vd., 2006; Barnett ve Kafka, 2007; Bixler, 2007; Kirby, 2003; Laprise ve Winrich, 2010; Lin vd., 2013; Ontell, 1997; Powell, 2009; Rose, 2003; Shaw ve Dybdahl, 2000; Yang, 2002); ulusal literatürde mevcut çalışmaların sayısının çok az olduğu tespit edilmiştir (Acar, 2003; Akbaş, 2011; Balbağ vd., 2012;Buluş Kırıkkaya vd., 2009; Ongel Erdal vd., 2004; Seçkin Kapucu, 2014; Yazıcı ve Altıparmak, 2010). Bu çalışmaların çalışılan örneklem ve uygulama konusu açısından çeşitli sınırlııklar taşıdığı görülmektedir. Bununla birlikte literatürde bilim-teknoloji-toplum hakkındaki görüşlere yönelik farklı çalışmalar bulunmasına rağmen, bilim kurgu filmler kullanılarak ilgili görüşlerin belirlendiği bir çalışma tespit edilememiştir. Brake ve Thornton'un (2003) üniversite öğrencileriyle yaptığı çalışmada, fen ve teknoloji okuryazarı bireyler yetiştirilmesi amacıyla, bilim kurgunun kullanımı üzerine odaklanılmıştır. Czerneda da (2006) bilim kurgu temelli aktivitelerin; bilimin nasıl çalıştığı gibi konuları ele aldığını, bunun yanı sıra fen okuryazarlığın temellerini de oluşturduğunu belirtmektedir. Araştırmada da benzer bir temadan yola çıkılarak, fen ve teknoloji okuryazarı bireylerin yetiştirilmesi amacıyla günlük yaşamımızda son zamanlarda sıklıkla karşımıza çıkan bilim kurgu filmlere yer verilmiş ve uygulamanın fen öğretmen adaylarının bilim-teknoloji-toplum hakkındaki görüşlerine olan etkisi incelenmiştir. Bu noktadan hareketle araştırmanın amacı; bilim kurgu filmlerin, fen bilgisi öğretmen adaylarının bilim-teknoloji-toplum hakkındaki görüşlerine olan etkisinin belirlenmesidir. Bu amaç doğrultusunda araştırma soruları aşağıda sunulmuştur:

- Öğretmen adaylarının uygulama öncesinde bilim-teknoloji-toplum hakkındaki görüşleri nelerdir?

- Bilim kurgu film uygulaması sonrasında öğretmen adaylarının görüşleri nasıldır? 


\section{YÖNTEM}

Bu bölümde araştırmanın modeli, çalışma grubu, araştırmanın uygulanması ile veri toplama ve analizi süreçlerine ilişkin ayrıntılı bilgi verilecektir.

\subsection{Araştırmanın Modeli ve Çalışma Grubu}

Araştırmada öğretmen adaylarının mevcut görüşlerinin belirlenmesi sürecinde nitel araştırma desenlerinden biri olan durum çalışması kullanılmıştır. Araştırma 2012-2013 öğretim yılı bahar döneminde gerçekleştirilmiş olup; araştırmanın çalışma grubunu i̇stanbul'da bulunan bir üniversitenin, ilköğretim bölümü fen bilgisi öğretmenliği $A B D$ ikinci sınıfında öğrenim görmekte olan 20 öğretmen adayı oluşturmaktadır. Öğretmen adayları 18-23 yaş aralığında olup bu öğretmen adaylarından $16^{\prime}$ sı kız, 4'ü ise erkektir. Araştırmanın örneklemi "kolay ulaşılabilir durum örneklemesi" ile belirlenmiştir. "Kolay ulaşılabilir durum örneklemesinde" araştırmacı yakın olan ve erişilmesi kolay olan bir durumu seçerek, araştırmaya hız kazandırmaktadır (Yıldırım ve Şimşek, 2013). Bu bağlamda araştırmaya katılan öğretmen adayları araştırmacı tarafından yürütülmekte olan 2 kredilik "fen bilimleri ve toplum" dersini alan öğretmen adayları arasından gönüllülük esas alınarak seçilmiştir.

\subsection{Araştırmanın Uygulanması}

Araştırma, veri toplama ve uygulama olmak üzere iki adımda gerçekleştirilmiştir. Araştırmanın uygulama süreci 5 hafta sürmüş ve bu süreçte araştırmacı tarafından seçilen bilim kurgu temelli 10 film izlenmiştir. Filmlerin seçiminde farklı fen kavram ve alanlarının (fizik, kimya, biyoloji) yer almasına özen gösterilmiştir. Ayrıca filmlerin seçiminde; filmin konusuna uygun olarak seçilen ve bu süreçte kullanılan farklı teknolojik araçlara da odaklanılmıştır. Böylece öğretmen adaylarının teknolojik araçların gelişimine, üretilmesine, bu süreçte yürütülen çalışmalara, bilim ile teknoloji arasındaki ilişkiye yönelik farkındalıklarının artması sağlanmıştır. Ayrıca bu süreçte öğretmen adaylarının filmde yer alan teknolojik araçların gündelik yaşamdaki olumlu/olumsuz etkileri gibi farklı başlıkları irdelemeleri de sağlanmıştır. Bu bağlamda teknolojik gelişmelerin toplumsal boyuttaki etkilerinin tartışılması hedeflenmiştir.

Uygulama sürecinde öğretmen adaylarının ikişer kişilik gruplar halinde çalışması istenmiş ve araştırmacı tarafından belirlenen kriterler doğrultusunda filmleri incelemeleri beklenmiştir. Öğretmen adayları filmleri, ilgili kriterler doğrultusunda inceledikten sonra sınıf ortamında sunmuşlardır. Bu süreçte öğretmen adaylarıyla bilim, bilim insanı, bilimsel çalışma süreci, bilim-teknoloji-toplum arasındaki ilişki gibi farklı konular da tartışılmıştır. Araştırmada kullanılan filmlere ve değerlendirme kriterlerine Tablo 1 'de yer verilmiştir.

Tablo 1

Öğretim Sürecinde Incelenen Filmler, liçerikleri ve Değerlendirme Kriterleri

\begin{tabular}{|c|c|c|}
\hline FILM & İ̧̧ERIK & DEĞERLENDIRME KRITERLERI \\
\hline $\mathrm{X}$ men & $\begin{array}{l}\text { Mutasyona uğrayan insanlar ve } \\
\text { toplumsal etkileri }\end{array}$ & $\begin{array}{l}\text { Filmin ana teması nedir? } \\
\text { Filmde hangi fen kavramları yer almaktadır? }\end{array}$ \\
\hline Savaş tanrısı & $\begin{array}{l}\text { Teknolojiyle birlikte silahlanma } \\
\text { ve etkileri }\end{array}$ & $\begin{array}{l}\text { Filmde yer alan fen kavramları, doğru } \\
\text { bilgiler içermekte midir? }\end{array}$ \\
\hline $\begin{array}{l}\text { Geleceğe dönüş II } \\
\text { Yarından sonra }\end{array}$ & $\begin{array}{l}\text { Farklı teknolojik gelişmeler } \\
\text { İnsanın doğa üzerindeki etkisi }\end{array}$ & $\begin{array}{l}\text { Fen kavramlarının, teknolojiyle olan } \\
\text { bağlantısı kurulmuş mudur? Nasıl? }\end{array}$ \\
\hline Zamanı durduranlar & Görelilik kuramı & Filmde yer alan bilim-teknoloji kurgusunun, \\
\hline 6. gün & $\begin{array}{l}\text { Genetik kopyalama } \\
\text { kullanılan teknolojiler }\end{array}$ & $\begin{array}{l}\text { toplum üzerinde etkileri var mıdır? Varsa } \\
\text { nelerdir? }\end{array}$ \\
\hline Ben robot & $\begin{array}{l}\text { Teknolojiyle birlikte robotların } \\
\text { insan yaşamına girmesi }\end{array}$ & $\begin{array}{l}\text { Filmde bilimsel yöntemin işleyişi } \\
\text { vurgulanmakta mıdır? }\end{array}$ \\
\hline Çekirdek & Dünyada meydana gelen bir & \\
\hline
\end{tabular}




\begin{tabular}{ll}
\hline \multirow{3}{*}{ Örümcek adam } & soruna bağlı olarak doğan \\
& toplumsal sonuçlar \\
& Genetiği değiştirilmiş bir \\
Armageddon & yapının kazanabileceği farklı \\
& özellikler \\
& Teknolojik tasarımlarla göktaşı \\
& çarpmasının engellenmesi \\
\hline
\end{tabular}

\subsection{Araştırma Verilerinin Toplanması}

Araştırma verileri nitel veri toplama yöntemlerinden biri olan "doküman incelemesi" ile toplanmıştır. Araştırmanın dokümanlarını "Bilim-Teknoloji-Toplum Anketi" (Turgut, 2005) ile sınıf içi tartışmalardan elde edilen "video kayıtları" oluşturmaktadır. Anket 8 sorudan oluşmaktadır. Bu anketin içerik ve görünüş geçerliği daha önce fen-teknoloji-toplum dersini yürütmüş bir fen eğitimcisi ile iki mühendisten oluşmuş üç üniversite öğretim üyesinin görüşüne başvurularak sağlanmıştır. Ankette yer alan sorulara Ek 1'de yer verilmiştir.

Araştırmada bilim kurgu filmlerin incelenmesi süreci, veri kaybı olmaması açısından kayıt altına alınmıştır. Video kayıtları yapılmadan önce öğretmen adaylarına neden video kaydı yapıldığı, ne tip bir araştırma yürütüleceği ve video kayıtlarının hangi amaç/amaçlarla kullanılacağı gibi farklı konulara ilişkin bilgi verilmiştir. Her bir video kaydı yaklaşık olarak 30-45 dk arasında olup, araştırmacı tarafından Word ortamında yazıya aktarılarak incelenmiş̧ir.

\subsection{Araştırma Verilerinin Analizi}

Öğretmen adaylarının bilim-teknoloji-toplum arasındaki ilişkiye yönelik görüşleri içerik analiziyle değerlendirilmiştir. Buna göre ankette yer alan sorular araştırmacı tarafından incelenerek kodlar oluşturulmuş ve bu kodlar temalaştırılarak tablo halinde sunulmuştur.

Öğretmen adaylarının bilim-teknoloji-toplum hakkındaki görüşlerinin belirlenmesi sürecinde sınıf içi tartışmaların tamamı kayıt altına alınmıştır. Araştırma sürecinde toplanan görsel verilerin tek başına veri kaynağı olmasından çok, araştırmadaki diğer veri toplama araçlarıyla birlikte kullanılması önerilmektedir (Baş ve Akturan, 2008). Bu nedenle kayıt altına alınan bu veriler araştırmacı tarafından yazıya aktarıldıktan sonra anketten elde edilen verileri desteklemek amacıyla kullanılmıştır.

Araştırmadan elde edilen nitel verilerin analizinin geçerlik ve güvenirliğinin sağlanması amacıyla araştırmacı ve veri çeşitlemesi yapılmıştır. Buna göre anketten elde edilen veriler, araştırmacının dışında fen eğitimi alanında uzman bir araştırmacı tarafından daha kodlanmış ve kodlamalar arasındaki tutarlılık hesabı Miles ve Huberman'ın (1994) uyum yüzdesi formülü ile belirlenmiş ve kodlamalar arasındaki tutarlılığın $\% 80$ 'in üzerinde olması durumunda araştırmanın güvenilir olduğu belirtilmiştir. Illgili formül ve araştırmacılar arasındaki uyum yüzdeleri her bir soru için Tablo 2'de verilmiştir.

$$
P=\frac{N a x 100}{N t}
$$

P: Uyum yüzdesi, Na: Aynı kodlanan öğrenci yanıtı sayısı, Nt: Kodlanan toplam öğrenci sayısı 
Tablo 2

Araştırmacı ve alan uzmanının oluşturulan kodlara ilişkin uyum yüzdeleri

\begin{tabular}{lc}
\hline BTTA Soruları & Uyum Yüzdesi \\
\hline 1.Soru & $\% 85$ \\
2.Soru & $\% 95$ \\
3.Soru & $\% 85$ \\
4.Soru & $\% 83$ \\
5.Soru & $\% 76$ \\
6.Soru & $\% 85$ \\
7.Soru & $\% 92$ \\
8.Soru & $\% 75$ \\
Ortalama & $\% 84.5$ \\
\hline
\end{tabular}

Tablo 2'de de görüldüğü gibi araştırmada, araştırmacılar arasındaki uyum yüzdesi \%85 olarak tespit edilmiştir. Bu bağlamda araştırmada yapılan analizin güvenilir olduğu düşünülmektedir. Bunun yanı sıra araştırma verilerinin toplanması ve analizi, araştırmanın uygulanması, verilerden elde edilen sonuçların doğrudan alıntılarla desteklenmesi, farklı veri toplama araçlarının bir arada kullanılarak veri çeşitlemesine gidilmesi gibi farklı yöntemler kullanılarak verilerin geçerlik ve güvenirliğinin sağlanması da amaçlanmıştır.

\section{BULGULAR}

Araştırmada uygulanan "bilim-teknoloji-toplum" anketinin ilk sorusunda öğretmen adaylarına sırasıyla "Teknoloji nedir? Mühendis kimdir? Teknoloji bilimden nasıl ayrılır?" soruları sorulmuştur. Elde edilen bulgulara Tablo 3'de sırasıyla yer verilmiştir.

Tablo 3

Birinci Soruya Ilişkin Bulgular

\begin{tabular}{|c|c|c|c|}
\hline \multirow{2}{*}{$\begin{array}{c}\text { Uygulama Öncesi } \\
\text { TEMA }\end{array}$} & \multicolumn{3}{|c|}{ Uygulama Sonrası } \\
\hline & f & TEMA & f \\
\hline \multicolumn{4}{|l|}{ a.Teknoloji nedir? } \\
\hline İhtiyaçlara göre materyal üretme & 15 & Hayatı kolaylaştırmak için yapılan yenilikler & 5 \\
\hline Hayatı kolaylaştıran yenilikler & 9 & İhtiyaçlar doğrultusunda ortaya çıkan ürün & 3 \\
\hline \multirow[t]{3}{*}{ Bilimin uygulanması } & 3 & Bilimin sonucunda ortaya çıkan ürün & 3 \\
\hline & & Yeni ürün üretme & 3 \\
\hline & & Teknik bilgi & 2 \\
\hline \multicolumn{4}{|l|}{ b.Mühendis kimdir? } \\
\hline Teknolojiyi tasarlayan kişi & 9 & Teknolojiyi uygulayan kişi & 9 \\
\hline Materyal tasarlayan kişi & 7 & İhtiyaçlara göre ürün üreten kişi & 5 \\
\hline İhtiyaçları somutlaştıran kişi & 2 & Teknolojik gelişmeleri bulan kişi & 3 \\
\hline Bilim ile teknolojiyi bağdaştıran kişi & 2 & Fizik-matematik alanında bilgili kişi & 2 \\
\hline \multicolumn{4}{|l|}{ c.Teknoloji bilimden nasıl ayrılır? } \\
\hline Bilim teknolojiyi-teknoloji de bilimi geliştirir & 16 & Teknoloji ile bilim birbirini destekler & 10 \\
\hline Teknoloji ürün oluşturma sürecidir & 3 & Teknoloji materyal üretme & 4 \\
\hline Bilim teknolojiyi kapsar & 2 & Bilim önce doğar-teknoloji sonra gelişir & 2 \\
\hline
\end{tabular}

Teknolojinin ne olduğuna ilişkin yapmış oldukları açıklamalara göre öğretmen adaylarının uygulama öncesinde vermiş oldukları yanıtların iki tema çerçevesinde yoğunlaştığı görülmektedir. Buna göre uygulama öncesinde öğretmen adayları teknolojiyi sıklıkla "hayatı kolaylaştırmak ve ihtiyaçları karşılamak için üretilen materyal" olarak tanımlamaktadırlar. Buna karşın uygulama sonrasında öğretmen adaylarının vermiş oldukları yanıtların farklı bir dağılım gösterdiği ve uygulama öncesinde yer alamayan yanıtları içerdiği de görülmektedir. Buna göre 
uygulama sonrasında öğretmen adaylarının teknolojiyi "bilim sonucunda ortaya çıkan ürün, yeni ürün üretme ve teknik bilgi" ifadeleri ile de açıkladıkları görülmektedir.

Öğretmen adayları uygulama öncesinde mühendisi sıklıkla "teknoloji ve materyal tasarlayan kişi" olarak açıklamışlardır. Uygulama sonrasında ise öğretmen adayları mühendisi sıklıkla "teknolojiyi uygulayarak, ihtiyaçlara göre ürün üreten kişi" olarak tanımlamışlardır. Elde edilen sonuçlarda da görüldüğü gibi öğretmen adaylarının uygulama öncesi ve sonrasında soruya ilişkin vermiş olduğu yanıtların paralel temalar içermekle birlikte; farklı başlıkları da içerdiği görülmektedir. Örneğin öğretmen adayları mühendisi uygulama öncesinde teknolojiyi tasarlayan; sonrasında ise uygulayan kişi olarak nitelemişlerdir. Bu durum öğretmen adaylarının zihinlerindeki kavram karmaşasını da ortaya koyar niteliktedir. Bunun yanı sıra öğretmen adayları uygulama öncesinden farklı olarak uygulama sonrasında mühendisin; fizik ve matematik alanlarında bilgili olması nedeniyle, teknolojik gelişmeleri bulma işlevinin olduğunu da düşünmektedirler. Buna karşın öğretmen adaylarının uygulama öncesinde mühendisin "bilim ile teknolojiyi bağdaştırarak, ihtiyaçları somutlaştıran kişi" olduğuna yönelik açıklamalarının da uygulama sonrasında yer almadığı görülmektedir.

Bilim ve teknoloji arasındaki farka ilişkin yapmış oldukları açıklamalarda ise öğretmen adayları uygulama öncesi ve sonrasında sıklıkla bilim ve teknolojinin birbirinden ayrılmayacağını ve birbirlerini destekleyecekleri yönünde görüş ortaya koymuşlardır. Bunun yanı sıra öğretmen adayları uygulama öncesi ve sonrasında "bilimin teknolojiyi kapsadığını ve teknolojinin materyal üretme süreci" olduğuna ilişkin yanıtlar verdikleri de görülmektedir. Öğretmen adaylarının uygulama öncesi ve sonrasında vermiş oldukları yanıtlar aşağıda örneklenmektedir.

"Teknoloji insan hayatını kolaylaştıran yenilikler bütünüdür. Mühendis teknolojiyi tasarlayandır. Bilim teknolojinin gelişmesini teknolojiyse bilimin gelişmesini sağlar." (Ön T., Ö1)

"Insanın hayatını kolaylaştıran tüm gelişmelere teknoloji denir. Mühendis teknolojik gelişmeleri uygulayan ya da bulan kişilere denir. Bilimin gelişmesiyle teknoloji gelişebilir." (Son T., Ö9)

Sınıf içerisinde yapılan tartışmalarda da öğretmen adayları bilim ve teknolojiye ilişkin görüşlerini belirtmişlerdir. İlgili alıntılar aşağıda örneklenmektedir.

A:İzlediğimiz filmleri düşünün lütfen. Filmlerde bilim ve teknolojiyi içeren pek çok örnek gördünüz. Burada yola çıkarak açıklarsanız sizce bilim ve teknoloji nedir?

Ö8: Insanların çevrelerini anlamlandırmak için geliştirdikleri fizik, kimya, biyoloji gibi alanlardan oluşan disiplin bilimdir bence. Teknoloji ise insanların ihtiyaçları doğrultusunda ortaya çıkmış ve çeşitli alet üretimini sağlayan gelişmelerdir.

Ö9: Doğa, çevre, toplum, teknolojinin bütünü ve bunların birbiriyle ilişkisinden elde edilen verilerdir bilim. Teknoloji ise bilim alanındaki gelişmelerle icat edilen nesnelerdir.

Ö5: İnsana kendisini, çevresini ve evreni öğretmeyi ve bunlar hakkında düşündürmeyi sağlayan alan bilimdir; insan yaşamını kolaylaştırmayı sağlayan icatların tümü de teknolojidir.

A: Peki bilim ve teknoloji arasında nasıl bir ilişki vardır?

Ö3: Birbirini tamamlayan iki kavramdır. Fen bilimdir. Teknoloji ise disiplinlerin yol göstericiliği ışığında ortaya çıkan, üretilen gelişmelerdir. i̇kisi bu açıdan birbirine bağlıdır. Fen bilimi geliştikçe teknoloji gelişir. Teknoloji geliştikçe de fen bilimi gelişir. 
A:O halde birbirlerinin gelişimini desteklerler diyebilir miyiz?

Sinıf: Evet.

Ö10: Kesinlikle evet hocam. Gelişen teknoloji ile birçok şeyi öğrendik. Teknoloji olmadan elimizdeki sınırlı imkanlarla ilerlemek mümkün değil bence.

Ö6: Teknolojinin gelişmesi fen alanında kolaylık sağlar.

Alıntılarda da görüldüğü gibi öğretmen adayları bilim ve teknolojinin birbirinden farklı kavramlar olduğunu düşünmektedirler. Yapılan açıklamalar öğretmen adaylarının teknolojinin intiyaçlar doğrultusunda oluştuğunu, çeşitli araçlar üretilerek insan yaşamını kolaylaştırmayı hedeflediğini ve bu süreçte de bilimin kullanıldı̆ııı belirtmişlerdir. Anketin ikinci sorusunda öğretmen adaylarına "yeni geliştirilen teknolojik araçlar bilime ve bilimsel araştırmalara ciddi katkılar sağlayabilir mi? Cevabınız "evet" ise ne tür katkılar sağlayabileceğini bazı örneklerle açıklayınız." sorusu sorulmuştur. Soruya ilişkin bulgulara Tablo 4'de yer verilmiştir.

Tablo 4

ikinci Soruya ilişkin Bulgular

\begin{tabular}{lclc}
\hline \multicolumn{1}{c}{\begin{tabular}{c} 
Uygulama Öncesi \\
\multicolumn{1}{c}{ TEMA }
\end{tabular}} & f & \multicolumn{2}{c}{ Uygulama Sonrası } \\
\hline Araştırma-inceleme yapmayı kolaylaştırma & 13 & Daha yeni alet üretme & f \\
Yeni ürün oluşturma & 10 & Bilinmeyeni keşif ve gelişim sağlama & 5 \\
Bilimin gelişmesini sağlama & 4 & & \\
Buluş yapmaya katkı sağlama & 2 & & \\
Düşüncelere kesinlik sağlama & 2 & & \\
\hline
\end{tabular}

Öğretmen adaylarının tamamı yeni gelişmelerin bilime ve bilimsel araştırmalara ciddi katkılar sağladığını düşünmektedirler. Öğretmen adayları uygulama öncesinde bu katkıları sıklıkla "araştırma-inceleme yapmayı kolaylaştırarak, yeni ürün oluşturmayı sağlama" olarak nitelemişler ve mikroskopun bulunmasını örnek olarak göstermişlerdir. Uygulama sonrasında ise öğretmen adaylarının sıklıkla "daha yeni alet üretme" yanıtını verdikleri görülmektedir. Öğretmen adaylarının uygulama öncesinde ve uygulama sonrasında vermiş oldukları yanıtlar aşağıda örneklenmektedir.

"Yeni gelişen teknoloji bilime katkı sağlar. Teknoloji ile araştırmalarda yardımcı olacak aletler de gelişir ve bu da bilime katkı sağlar. Örnek verecek olursa; eskiden yediğimiz besinlerin yapısını incelemek zordu. Zamanla teknolojinin gelişmesiyle önce ışın mikroskobu bulunmuş, besinlerin yapısı daha anlaşılır hale gelmiştir."(Ön T., Ö14)

"Sağlar, çünkü bilimin sayesinde gerçekleşen teknoloji araçları ileri safhalarda daha iyi araçların var olmasıyla araştırmaları daha kolay yapmaktadırlar." (Son T., Ö2)

Elde edilen bulgularda da görüldüğü gibi öğretmen adaylarının uygulama sonrasında vermiş oldukları yanıtların nitelik ve nicelik bakımından azaldığı görülmektedir. Ayrıca uygulama sonrasında verilen cevapların sıklıkla "yeni alet üretme" yanıtı üzerine yoğunlaştığı da belirlenmiştir. Sınıf içi tartışmalarda da öğretmen adayları ilgili konuya ilişkin görüşlerini belirtmişlerdir. İlgili alıntılara aşağıda yer verilmiştir.

A: İzlediğimiz filmde teknolojik pek çok araç gördünüz. Bu teknolojik araçların gelişmesi veya teknolojinin gelişmesi bilime katkı sağlar mı?

Sınıf: Evet.

A:Nasıl bir katkı sağlar? 
Ö7: Teknolojiyle gelişen fen bilimi ve fen bilimi geliştikçe daha da gelişmeye ihtiyaç duyan teknoloji ortaya çıkar. Bu da toplumu doğrudan geliştirir.

Ö6: Fenle ilgili bulunan bir şey, teknoloji için yarar sağlar. Teknoloji ilerledikçe fen alanındaki yenilikler artar.

Ö1: Teknoloji gelişmek için yeni bilgileri bilimden yani fenden alır. Fende yeni araştırmalar yapabilmek için teknolojiden faydalanır.

Alıntılarda da görüldüğü gibi öğretmen adayları bilim ve teknoloji arasında döngüsel bir ilişki olduğunu düşünmektedirler. Öğretmen adayları teknolojinin bilimi etkilediğini; buna ek olarak bilimin de teknolojiyi etkilediğini belirtmişlerdir. Anketin üçüncü sorusunda öğretmen adaylarına "teknolojinin bilimsel araştırmalarda yönlendirici olma, motivasyon sağlama gibi rolleri olabilir mi? Cevabınız "evet" ise bazı örneklerle açıklayınız." sorusu sorulmuş ve ilgili bulgulara Tablo 5'de yer verilmiştir.

Tablo 5

Üçüncü Soruya ilişkin Bulgular

\begin{tabular}{llcc}
\hline \multicolumn{1}{c}{ Uygulama Öncesi } & \multicolumn{2}{c}{ Uygulama Sonrası } \\
\multicolumn{1}{c}{ TEMA } & f & TEMA & f \\
\hline Üretilen materyallere yardımcı olma & 4 & Çaresi olmayan hastalıklara çözüm bulma & 5 \\
Araştırmada yönlendirici olma & 4 & Daha meraklı olmayı sağlama & 5 \\
Çalışmaları kolaylaştırma & 3 & & \\
Daha kısa sürede yapmayı sağlama & 3 & & \\
Daha kapsamlı bilgiye ulaşmayı sağlama & 3 & & \\
Sonuca kolay ulaşmayı sağlama & 2 & & \\
Bilimsel merakı etkileme & 2 & & \\
\hline
\end{tabular}

Öğretmen adaylarının tamamı hem uygulama öncesi hem de sonrasında teknolojinin bilimsel araştırmalarda yönlendirici olma ve motivasyonu sağlama rollerinin olduğunu ifade etmişlerdir. Öğretmen adayları uygulama öncesinde teknolojinin bilimsel araştırmalarda sıklıkla "yönlendirici olma, üretilen materyallere yardımcı olma, çalışmaları kolaylaştırma, süreyi kısaltma ve daha kapsamlı bilgiye ulaşma" gibi rollerinin olacağını belirtmişlerdir. Uygulama sonrasında ise öğretmen adaylarının sıklıkla "çaresi olmayan hastalıklara çözüm bulma ve ürünleri geliştirme süreci ile birlikte daha meraklı olmayı sağlama" konularında rollerinin olacağını belirtmişlerdir. Öğretmen adaylarının uygulama öncesi ve sonrasında vermiş oldukları yanıtlar aşağıda örneklenmektedir.

"Evet. Birçok bilim insanı günümüzde teknolojiden faydalanarak daha kısa sürede ve daha kapsamlı şekilde istediklerine ulaşabilmektedir. Bu da onların motive olmaları için bir sebeptir. Araştırılan konuya göre teknik imkânlar araştırmalara yön verebilir." (Ön T., Ö16)

"Evet olabilir. Örnek olarak; şu an teknolojinin gelişmesiyle daha önce çaresi olmayan hastalıklara tedavi yöntemleri geliştirilmiştir. Bu da insanlar için bir umut olmuştur." (Son T., Ö5)

Verilen yanıtlarda da görüldüğü gibi öğretmen adayları teknolojinin bilimsel araştırmalara yönelik farklı etkilerinin olduğunu düşünmektedirler. Ayrıca elde edilen sonuçlar uygulama sonrasında öğretmen adaylarının vermiş oldukları yanıtların, uygulama öncesine oranla oldukça azaldığını da ortaya koymaktadır. Öğretmen adayları soruya vermiş oldukları yanıtların benzerlerini sınıf içi tartışmalarda da ifade etmişlerdir. ilgili tartışmalara yukarıda yer verilmesi nedeniyle, alıntılar yeniden tekrarlanmamıştır. Anketin dördüncü sorusunda 
öğretmen adaylarına "teknolojik tasarımlar yardımıyla gündelik yaşantımızdaki tüm sorunları çözebilir miyiz? Örnek veriniz." sorusu sorulmuştur. Soruya ilişkin bulgulara Tablo 6'da yer verilmiştir.

Tablo 6

Dördüncü Soruya ilişkin Bulgular

\begin{tabular}{|c|c|c|c|}
\hline \multirow{2}{*}{$\begin{array}{l}\text { Uygulama Öncesi } \\
\text { TEMA }\end{array}$} & \multicolumn{3}{|c|}{ Uygulama Sonrası } \\
\hline & f & TEMA & $f$ \\
\hline Hayır & 14 & Hayır & 8 \\
\hline Kısmen & 7 & Kısmen & 7 \\
\hline Evet & 2 & Evet & 1 \\
\hline
\end{tabular}

Tablo 6'da da görüldüğü gibi öğretmen adayları hem uygulama öncesi hem de sonrasında soruya sıklıkla "hayır" yanıtını vermişlerdir. Soruyu bu şekilde yanıtlayan öğretmen adaylarının uygulama öncesinde "teknolojik tasarımların psikolojiyi bozması, telefonların kolaylık olması ancak şarjının sorun olması, artan ihtiyaçların zamanla karşılanamaması, henüz yapılmamış araçların olması" gibi örnekler verdikleri görülmektedir. Uygulama sonrasında ise bu şekilde düşünen öğretmen adaylarının "psikolojik sorunlar çözülmez, klonlama önemli ancak etik sorunlar oluşabilir, nükleer enerji etkili ancak sağlık sorunları oluşabilir, tıp ne kadar gelişse de hastalıklar çözülemeyebilir" şeklinde farklı örnekler verdikleri tespit edilmiştir. Bunun yanı sıra uygulama öncesi ve sonrasında teknolojik tasarımların tüm sorunları çözeceğini düşünen öğretmen adaylarının olduğu da görülmektedir. Bu şekilde düşünen öğretmen adaylarının uygulama öncesinde "acil durumlarda telefon edebilme ve telefonda görüntülü konuşma yapabilme"; uygulama sonrasında ise "boyu kısa birinin merdiven kullanması" örneklerini verdikleri görülmektedir.

Kısmen yanıtını veren öğretmen adayları uygulama öncesinde "teknolojik gelişmelerin ulaşım ve iletişim gibi pek çok sorunun çözebileceğini ancak tamamına çözüm getiremeyeceğini; bunun yanı sıra cep telefonu, bilgisayar gibi teknolojik araçların kullanışlı olmakla birlikte radyasyon sorununu da beraberinde getirdiğini" belirtmişlerdir. Uygulama sonrasında ise "gelişmekte olan ve hayatı kolaylaştıran teknolojinin kanseri ve psikolojik sorunları getirmesi nedenleriyle; bazen sorunun kendisi olabileceğini" düşünmektedirler. Öğretmen adaylarının uygulama öncesi ve sonrasında vermiş oldukları yanıtlar aşağıda örneklenmektedir.

"Teknolojik tasarımlar şimdilik gerekli bazı ihtiyaçlarımızı karşılayabiliyor yalnız tamamının yeterli olduğunu sanmıyorum ve bilimsel gelişim sonucunda artan ihtiyaçlar zamanla karşılanabilir." (Ön T., 21)

"Çözemeyiz. Teknoloji sonucunda oluşan psikolojik veya toplumsal sorunları teknoloji yöntemiyle halledemeyiz." (Son T., Ö9)

Elde edilen bulgularda da görüldüğü gibi öğretmen adayları teknolojik tasarımların hayatımızdaki sorunların çözümüne yönelik farklı etkilerinin olduğunu düşünmektedirler. Öğretmen adayları sıklıkla teknolojik tasarımların hayatımızdaki tüm sorunları çözmeyeceğini veya kısmen çözeceğini düşünmektedirler. Sınıf içerisinde yapılan tartışmalarda da öğretmen adayları ilgili konuya yönelik görüşlerini dile getirmişlerdir. Sınıf içerisinde yapılan tartışmaların bir bölümü aşağıdaki alıntılarda örneklenmektedir.

A:Günümüzde artık pek çok sorunumuzu teknolojik araçlar kullanarak kolaylıkla çözebiliyoruz. Filmde de buna ilişkin farklı örnekler gördük. Örneğin günlük yaşamımızdaki telefonları düşünün. Telefonlarımızla artık neredeyse her sorunumuzu 
çözüyoruz. Siz ne düşünüyorsunuz bu konuda? Teknoloji sizce de her sorunumuzu çözüyor mu?

Ö8: Evet hocam bence de telefonlar her sorunumuzu çözüyor. Bir şeyler araştıracağım zaman ya da uzaktaki birisiyle iletişim kurmam gerektiği zaman hızlıca her işimi çözüyorum.

Ö1: Hocam ben böyle düşünmüyorum. Teknolojik araçlar her sorunu çözemez. Bazen bence sorunun kendisi de olabilir. Cep telefonu dedik. Cep telefonu hayatımızda önemli bir araç ama beraberinde yayılan radyasyon ve çeşitli dalgalar, insan sağlığı üzerine de etki ediyor.

Ö2: Evet bence de hocam. Kanseri ele alalım. Kanserin çözümünü bulabildik mi? Ya da AIDS'i çözebildik mi? Hayır. Peki ya ruhsal sorunlar nasıl çözülecek. Bence imkansız teknoloji her şeyi çözemez.

Ö10: Hocam ben katılmıyorum. Bence şu an çözmüyor ama bu çözemeyeceği anlamına gelmez. Bence bir gün her sorun çözülecek.

Alıntılarda da görüldüğü gibi öğretmen adayları teknolojinin tüm sorunları çözüp çözemeyeceğine ilişkin farklı görüşler ortaya koymaktadırlar. Sınıf içi tartışmalarda da öğretmen adayları çeşitli sağlık sorunları üzerine vurguda bulunmuş ve teknolojinin sorunların çözümü açısından yeterli kalmayabileceğini belirtmişlerdir. Anketin beşinci sorusunda öğretmen adaylarına "teknolojik araçların gündelik hayata etkileri konusundaki düşüncelerinizi örnekle açıklayınız" sorusu sorulmuştur. Soruya ilişkin bulgulara Tablo 7'de yer verilmiştir.

Tablo 7

Beşinci Soruya iliş̧kin Bulgular

\begin{tabular}{lccc}
\hline \multicolumn{1}{c}{ Uygulama Öncesi } & & Uygulama Sonrası & TEMA \\
\multicolumn{1}{c}{ TEMA } & f \\
\hline Hayatı kolaylaştırma & f & Olumlu-olumsuz etkileri olma & 11 \\
Olumlu-olumsuz etkileri olma & 15 & Hayatı kolaylaştırma & 7 \\
Vakit kazandırma & 4 & & \\
Pratikleştirme & 2 & & \\
Asosyalleşmeye neden olma & 2 & & \\
\hline
\end{tabular}

Öğretmen adayları hem uygulama öncesi hem de sonrasında teknolojik araçların sıklıkla "hayatı kolaylaştırdığını bunun yanı sıra olumlu/olumsuz etkilerinin olabileceğini" belirtmişlerdir. Öğretmen adayları uygulama öncesinde teknolojinin kolay iletişim kurmaya neden olma, kolay araştırma yapma imkânı sunma ve günlük yaşamımızı kolaylaştırma gibi olumlu etkilerinin yanında; radyasyon, savaş ve asosyalleşmeye neden olma gibi olumsuz etkilerinin olduğunu da düşünmektedirler. Uygulama sonrasında ise öğretmen adayları teknolojinin hayatı kolaylaştırma gibi olumlu etkilerinin yanı sıra; sosyalliği azaltma, trafik, kirlilik ve sağlık sorunları oluşturma gibi pek çok sorunu yarattığını da düşünmektedirler. Öğretmen adaylarının uygulama öncesi ve sonrasında vermiş oldukları yanıtlar aşağıda örneklenmektedir.

"Teknolojik araçlar gündelik yaşantımızı büyük ölçüde kolaylaştııır. En basitinden mutfaktaki robottan, tarlada çalışan çiftçinin tarlayı motor gücüyle sürmesine kadar her alanda teknoloji vardır. Teknolojinin her zaman olumlu etkileri olacak diye bir durum söz konusu değil tatbikî olumsuz etkileri de vardır. En bilinen örnek Çernobil faciası gibi. Hala gündelik hayatı büyük ölçüde etkilemektedir." (Ön T., Ö18) 
"Teknolojik aletler üretilme amacı insanlara faydalı veya hayatlarının kolaylaştırmak amaçlı olsa da zararlı yönleri de olabilir. Hayatımızı çoğunlukla kolaylaştırırlar." (Son T., Ö11)

Elde edilen bulgularda da görüldüğü gibi öğretmen adayları uygulama öncesinde soruya ilişkin daha fazla sayıda açıklamada bulunurken, uygulama sonrasında yapılan açıklamaların sayısının azaldığı görülmektedir. Bununla birlikte öğretmen adayları teknolojinin etkilerine ilişkin farklı görüşler ortaya koyarken, uygulama öncesi ve sonrasında ortak temalara da yer vermişlerdir. Öğretmen adayları sınıf içi tartışmalarda da ilgili soruya yönelik açıklamalarda bulunmuşlardır. Sınıf içerisinde yapılan tartışmaların bir bölümü aşağıdaki alıntılarda örneklenmektedir.

A:Filmde gördük ki teknoloji hayatımızın pek çok noktasında mevcut. Ancak mevcut etkileri farklı. Peki sizce teknolojik araçlar hayatımızı nasıl etkiler?

Ö1: Bize büyük kolaylık sağlar. Bilimdeki ilerleme teknolojiye yansır, bu da toplumu etkileyerek hayatımızı kolaylaştırır.

Ö6: Fen ve teknoloji toplumu etkilerken, toplumların hayatları değişirken içinde bulundukları çevre de olumlu ya da olumsuz yönde etkilenir. Örneğin telefonları konuşmuştuk. Hayatımız için büyük bir kolaylık ancak olumsuz pek çok da etkisi var. Şimdilik bunları göz önüne almıyoruz yalnızca.

Ö3: Teknolojinin gelişmesi ile toplum duyarlık kazanır, çevreyi korumak için çeşitli yöntemler-aletler geliştirir. Aynı zamanda zararı da olabilir.

Sınıf içerisinde yapılan tartışmalarda da görüldüğü gibi öğretmen adayları ankette vermiş olduklarına benzer yanıtlar vermişlerdir. Buna göre sınıf içerisindeki tartışmalarda da öğretmen adaylarının teknolojinin olumlu yönlerine vurguda bulundukları buna karşın olumsuz yönlerine atıfta bulundukları da görülmektedir. Anketin altıncı sorusunda öğretmen adaylarına "sizce en uygun mühendislik tasarımlarında hangi şartların sağlanması gerekir açıklayınız" sorusu sorulmuştur. Soruya ilişkin bulgulara Tablo 8' de yer verilmiştir.

Tablo 8

Altıncı Soruya iliş̧kin Bulgular

\begin{tabular}{llll}
\hline \multicolumn{1}{c}{\begin{tabular}{c} 
Uygulama Öncesi \\
\multicolumn{1}{c}{ TEMA }
\end{tabular}} & f & \multicolumn{1}{c}{$\begin{array}{c}\text { Uygulama Sonrası } \\
\text { TEMA }\end{array}$} & f \\
\hline İnsana-çevreye zararsız olma & 12 & Çevreye zarar vermeme & 9 \\
Ekonomik olma & 11 & Maliyeti düşük olma & 9 \\
Ihtiyaçları karşılama & 8 & Topluma yararlı olma & 7 \\
Kullanışlı olma & 6 & Sağlığa zarar vermeme & 6 \\
Verimli olma & 2 & Topluma zarar vermeme & 4 \\
& & Geri dönüşümlü olma & 3 \\
& & İş güvenliğine sahip olma & 3 \\
& Bilime katkı sağlama & 3 \\
& & Hayatı kolaylaştırma & 2 \\
& & Etik olma & 2 \\
& & Sağlam malzeme kullanma & 2 \\
\hline
\end{tabular}

Tablo 8'de de görüldüğü gibi öğretmen adayları uygulama öncesi ve sonrasında soruya ilişkin farklı açıklamalarda bulunmuşlardır. Uygulama öncesinde öğretmen adayları teknolojik tasarımların sıklıkla "insana-çevreye zararsız, maliyeti düşük ve kullanışlı olması; ayrıca ihtiyaçları karşılaması gerektiğini" belirtmişlerdir. Uygulama sonrasında ise öğretmen adayları teknolojik tasarımların sıklıkla "çevreye, topluma ve sağlığa zarar vermemesi, maliyetinin düşük 
olması ve yarar sağlaması" gerektiğini ifade etmişlerdir. Öğretmen adaylarının uygulama öncesi ve sonrasında vermiş oldukları yanıtlar aşağıda örneklenmektedir.

"En uygun mühendislik tasarımları insan ve çevre sağlığı göz önünde bulundurularak yapılmalıdır." (Ön T., Ö17)

"Çevreye zarar vermemeli, insanlara psikolojik sorunlar yaratmamalı, doğal kaynaklara zarar vermemeli, işlenebilir olmalı." (Son T., Ö12)

Elde edilen bulgularda da görüldüğü gibi uygulama sonrasında öğretmen adaylarının vermiş oldukları yanıtlar hem nitelik hem de nicelik bakımından, uygulama öncesine göre farklııı göstermektedir. Bunun yanı sıra öğretmen adayları uygulama öncesi ve sonrasında teknolojik tasarımların öncelikli olarak çevreye zarar vermemesi gerektiğini düşünmektedirler. Sınıf içerisinde yapılan tartışmalarda ilgili anket sorusuna ilişkin her hangi bir veri elde edilememiştir. Bu nedenle anketin bu sorusu için her hangi bir alıntı sunulamamıştır. Anketin yedinci sorusunda öğretmen adaylarına "teknolojik sistemlerin, tasarımların başarısız olma intimalini tamamıyla ortadan kaldırabilmek mümkün müdür?" sorusu sorulmuştur. Soruya ilişkin bulgulara Tablo 9'da yer verilmiştir.

Tablo 9

Yedinci Soruya Illişkin Bulgular

\begin{tabular}{llll}
\hline \multicolumn{1}{c}{ Uygulama Öncesi } & \multicolumn{1}{c}{ Uygulama Sonrası } \\
\multicolumn{1}{c}{ TEMA } & f & \multicolumn{1}{c}{ TEMA } & f \\
\hline Insan ürünü olduğu için & 6 & Hata her zaman olabileceği için & 7 \\
Hata payı olacağı için & 4 & Bilim sürekli geliştiği için & 3 \\
İcat edilenler her zaman yarar sağlayamayacağı için & 2 & Bilim deneme-yanılmayla çalıştığı için & 2 \\
\hline
\end{tabular}

Öğretmen adayları hem uygulama öncesi hem de sonrasında teknolojik tasarımların başarısız olma ihtimalinin ortadan kaldırılabileceğini düşünmemektedirler. Öğretmen adayları uygulama öncesinde teknolojik tasarımların "insan ürünü olması, hata payının olması ve icat edilenlerin her zaman yarar sağlamaması"; uygulama sonrasında ise "her zaman hatanın olması, bilimin sürekli gelişmesi ve bilimin deneme-yanılmayla çalışması" nedenleriyle başarısız olma ihtimalinin ortadan kaldırılamayacağını belirtmişlerdir. Öğretmen adaylarının uygulama öncesi ve sonrasında vermiş oldukları yanıtlar aşağıda örneklenmektedir.

"Hataların başarısız olma ihtimallerini ortadan kalkması mümkün değildir. Çünkü teknolojinin gelişmesi insanın emek ve çabalarıyla gerçekleşir. İnsanların katkıda bulundukları şeyler de hatalar olabilir." (Ön T., Ö14)

"Her zaman daha iyisi olabilir düşüncesiyle bilim de sürekli gelişip, yenilenebilir. Dolayısıyla başarısızık başarıyı getirir. Yani başarısız olma intimalini tamamıyla ortadan kaldıramayız." (Son T., Ö14)

Elde edilen bulgularda da görüldüğü gibi öğretmen adayları uygulama öncesi ve sonrasında nicelik bakımından aynı sayıda yanıt vermişlerdir. Verilen yanıtlar incelendiğinde ise öğretmen adaylarının uygulama öncesi ve sonrasında sayısı azalmış olsa da "hatanın her zaman olabileceğine" yönelik ortak bir açıklamada bulundukları görülmektedir. Sınıf içerisindeki tartışmalarda da ilgili soruya ilişkin veriler elde edilmiştir. Alıntılar aşağıda örneklenmektedir.

A:Filmde gördük. Bilim insanları tasarlamış oldukları aracı çalıştırma sürecinde sorun yaşadılar maalesef. Ardından farklı çözüm yolları düşünerek sorunlarını çözmeye çalıştılar. Peki bu sorunları sıfıra indirmek mümkün müdür sizce? Sorunsuz bir tasarım yapılamaz mı? 
Sınıf: Hayır

A: Neden?

Ö10: Ne kadar teknoloji gelişirse gelişsin, nihayetinde her şey insan yapımı hocam. Her türlü sorun insanı ve yaptığı çalışmaları etkileyebilir.

Ö2: Sıfır hata mümkün değil hocam.

Ö9: Bence de hocam. Robot yapıyoruz her şeyi onlara emanet ediyoruz. Zamanla bu daha da artacak. Ancak robotları da bizler yapıyoruz. Dolayısıyla hata her zaman olacaktır diye düşünüyorum.

Alıntılarda da görüldüğü gibi öğretmen adayları hataların önüne geçilemeyeceği görüşündedirler. Anketin sekizinci sorusunda öğretmen adaylarına "bir ülkede ya da toplumda geliştirilebilecek teknolojileri belirleyen faktörler nelerdir örnekle açıklayınız" sorusu sorulmuştur. Soruya ilişkin bulgulara Tablo 10’da yer verilmiştir.

Tablo 10

Sekizinci Soruya ilişkin Bulgular

\begin{tabular}{llll}
\hline \multicolumn{1}{c}{$\begin{array}{c}\text { Uygulama Öncesi } \\
\text { TEMA }\end{array}$} & f & \multicolumn{1}{c}{$\begin{array}{c}\text { Uygulama Sonrası } \\
\text { TEMA }\end{array}$} & f \\
\hline Ekonominin iyi olması & 8 & Ekonomik durum & 11 \\
Halkın ihtiyacı & 7 & Toplum & 9 \\
Ülkenin kalkınma seviyesi & 5 & Çevre & 5 \\
Eğitim şartlarının iyi olması & 4 & Eğitim seviyesi & 5 \\
Eğitimin önemsenmesi & 3 & Sağlığa zarar vermemesi & 3 \\
Doğa ve toplumun zarar görmemesi & 2 & İhtiyaçlar & 3 \\
Konuya duyulan merak & 2 & Toplumun yararına olması & 3 \\
& & Coğrafi durum & 2 \\
& & Bilim insanı & 2 \\
& & Ülkeler arası ilişkiler & 2 \\
& & Etik olması & Olumlu-olumsuz yönlerin olması \\
& & & 2 \\
\hline
\end{tabular}

Tablo 10'da da görüldüğü gibi öğretmen adayları bir ülkedeki teknolojileri belirleyebilecek faktörleri uygulama öncesinde sıklıkla "iyi bir ekonomi, halkın ihtiyaçları, ülkenin kalkınma seviyesi, eğitim şartlarının iyi olması ve eğitimin önemsenmesi" ile ilişkilendirmişlerdir. Uygulama sonrasında ise öğretmen adaylarının sıklıkla "ekonomik durum, toplum, çevre, eğitim seviyesi, sağlığa zarar vermeme, ihtiyaç ve toplumun yararına olma" yanıtlarını verdikleri görülmektedir. Öğretmen adaylarının uygulama öncesi ve sonrasında vermiş oldukları yanıtlar aşağıda örneklenmektedir.

"Toplumda geliştirilebilecek teknolojileri belirleyen unsurlar, o ülkenin ekonomisi, kalkınmışlık seviyesi, eğitim durumlarını etkiler." (Ön T. , Ö11)

"Bu teknolojilerin çevreye vereceği yararları ve zararları değerlendirmek gerekir. Etik olmalı, sağlığa zarar vermemeli, toplumun yararına olmalıdır." (Son T., Ö18)

Elde edilen bulgularda da görüldüğü gibi öğretmen adaylarının uygulama sonrasında soruya ilişkin vermiş oldukları yanıtlar nitelik ve nicelik bakımından uygulama öncesine göre farklılaşmaktadır. Uygulama sonrasında alınan yanıtların uygulama öncesinde elde edilmeyen farklı temaları da içerdiği görülmektedir. Sınıf içerisindeki tartışmalarda da öğretmen adayları soruya ilişkin görüşlerini ortaya koymuşlardır. Alıntılar aşağıda örneklenmektedir. 
A:İzlediğimiz filmlerde pek çok teknolojik tasarıma rastladık. Sizce bu tasarımlar ülkemizde de üretilmekte midir?

Ö4: Evet hocam mesela filmde genetiği ile oynanan çeşitli durumlara rastladık. Bizim ülkemizde de yapılıyor benzeri çalışmalar.

A:Evet haklısın. Ancak bir önceki filmimizde uzayda yapılan çeşitli çalışmalara yer veriliyordu. Bizim ülkemizde ne tip çalışmalar var bununla ilgili?

Ö3: Hocam biz de pek çok şey üzerinde çalışıyoruz. Ancak bazen farklı sorunlar ortaya çıkabiliyor. Örneğin maliyeti yüksek olan bir işe belki de giremiyoruz sırf bu nedenden dolayı. Ya da bazen ülkeler arası sorunlar bile bu durumu etkileyebiliyor.

Ö6: Evet hocam bunlar etken bence de. Arkadaşımız doğru söyledi. Biz ülkemizde çeşitli çalışmaları yapabiliyoruz belki. Ama yapamadıklarımız da var. Belki de o alana ilgi duyan kimse yok bu alanda çalışan araştırmacı yok. Olamaz mı?

A: Bu durumda teknolojik tasarımları yaparken farklı etkenler mi bu süreci etkiliyor?

Sinıf: Evet

Alıntılarda da görüldüğü gibi öğretmen adayları teknolojik tasarımların geliştirilmesi sürecinde farklı faktörlerin etkili olabileceğini düşünmektedirler.

\section{TARTIŞMA VE SONUÇ}

Araştırmada öğretmen adaylarının bilim-teknoloji-toplum hakkındaki görüşlerinin uygulama öncesi ve sonrasında doğru ve yeterli niteliklere sahip olduğu görülmektedir. Araştırmadan elde edilen bu sonuç araştırmaya katılan öğretmen adaylarının ilgili başlıklara ilişkin bilgi sahibi olduklarını da ortaya koymaktadır. Özdemir'in (2010) yapmış olduğu araştırmada da fen ve teknoloji öğretmen adaylarının fen-teknoloji-toplum-çevre ilişkisini anladıkları tespit edilmiştir. Elde edilen bu sonuçlara karşın Thier (1985) öğrencilerin bilimteknoloji-toplumla ilgili konularda genellikle düşük bilgi düzeyinde olduğunu belirmiştir. Bu araştırmadan elde edilen sonuç ise bu durumun aksini ortaya koyar niteliktedir. Araştırmalarda ortaya konan bu farklılı̆ın, uygulama zamanı ve grubu ile doğrudan ilişkili olabileceği; ayrıca öğretmen adaylarının almış oldukları ders gereği ilgili başıılara aşina olmaları ile de ilişkili olabileceği düşünülmektedir. Araştırmada elde edilen bu sonucun yanı sıra; uygulama sonrasında öğretmen adaylarının görüşlerinin nicelik ve nitelik bakımından farklılaştığı da görülmektedir. Bu bağlamda bilim kurgu filmlerin bilim-teknoloji-toplum hakkındaki görüşlere yönelik katkısının, görüşlerin nicelik ve niteliğini artırma bakımından olumlu katkı sağladığı söylenebilir.

Bilim-teknoloji-toplum anketine (Turgut, 2005) vermiş oldukları yanıtlar ayrıntılı bir şekilde incelendiğinde ise öğretmen adaylarının teknolojiyi uygulama öncesinde "ihtiyaçlar doğrultusunda üretilen ve hayatı kolaylaştıran materyaller"; uygulama sonrasında ise "bilimsel çalışmayla, ihtiyaçlar doğrultusunda ortaya çıkan ve hayatı kolaylaştıran ürünler" olarak açıkladıkları görülmektedir. Sınıf içi tartışmalarda da öğretmen adayları bilim ve teknolojinin birbirinden farklı kavramlar olduğunu belirtmiş; bunun yanı sıra teknolojinin ihtiyaçlar doğrultusunda oluştuğunu, çeşitli araçlar üretilerek insan yaşamını kolaylaştırmayı hedeflediğini ve bu süreçte de bilimin kullanıldığını ifade etmişlerdir. Turgut'un (2005) yapmış olduğu araştırmada ise öğretmen adaylarının teknolojiyi "araç geliştirme ve tasarlama süreci" olarak niteledikleri görülmektedir. Uğraş ve Cil'in (2012) yapmış olduğu araştırmada da fen bilgisi öğretmen adayları, teknoloji kavramını fenin uygulaması olarak nitelemişlerdir. Farklı araştırmalarda da görüldüğü gibi öğretmen adayları bilim ve teknoloji kavramına ilişkin farklı 
açıklamalarda bulunmakta ve iki kavramın doğası gereği ayrı nitelenmesi gerektiğine vurguda bulunmaktadırlar.

Öğretmen adayları hem uygulama öncesi hem de sonrasında teknolojik araçların hayatı kolaylaştırdığını; ancak tüm sorunları çözemeyeceğini, trafik, kirlilik, sağlık, radyasyon ve asosyalleşme gibi olumsuz etkilerinin olabileceğini belirtmişlerdir. Toraman ve Aydın'ın (2013) yapmış olduğu araştırmada da öğretmen adayları teknolojik araçların hayatı kolaylaştırdığını; ancak bireylerin sosyalleşmesine engel olduğuna, hastalıkların artmasına, doğal kaynakların kaybedilmesine, tüketime olan ilginin artmasına, kültürel ve moral değerlerin kaybedilmesine, farklı tehlikelerin yer aldığı, güvensiz, kirlenmiş, doğal olmayan ve su kaynaklarının tükendiği bir dünyanın var olmasına neden olacağını ifade etmişlerdir. Ankette yer alan başka bir soruya vermiş oldukları yanıtlarda ise öğretmen adayları, teknolojik tasarımların gündelik yaşamdaki tüm sorunları çözemeyeceğini ifade etmişlerdir. Öğretmen adaylarının bu konuya ilişkin uygulama öncesinde "psikolojik sorunların çözülememesi, henüz yapılmamış araçların olması ve artan ihtiyaçların karşılanamaması"; uygulama sonrasında ise "psikolojik sorunların ve hastalıkların çözülememesi, etik ve sağlık gibi çeşitli sorunların oluşabilmesi" şeklinde örnekler vermişlerdir. Uğraş ve Cil'in (2012) araştırmasında da öğretmen adayları günlük sorunların çözümü için deneyim ve duyguya ihtiyaç duyulacağını belirtilmişlerdir. Farklı araştırmalardan elde edilen sonuçlarda da görüldüğü gibi öğretmen adayları teknolojik tasarımların günlük yaşamımızdaki tüm sorunları çözemeyeceği, "insan" faktörünün önemli bir etmen olduğu ve bu süreçte duygu, düşünce... gibi sosyal yönlerinin de göz önüne alınması gerektiğini düşünmektedirler.

Öğretmen adayları çoğunlukla bilim ve teknolojinin birbirinden ayrılmayacağını ve birbirine paralel bir şekilde geliştiğini düşünmektedirler. Uğraş ve Cil'in (2012) araştırmasında da fen öğretmen adayları fen alanındaki araştırmalar ve teknolojik alandaki uygulamalar ile teknolojik gelişmeler ve fen alanındaki araştırmaların artışının birbiriyle doğru orantılı olduğunu ifade etmişlerdir. Elde edilen benzer sonuçlara karşın, araştırmada öğretmen adaylarının bir bölümünün bilim ve teknolojinin birbirinden ayrıldığını düşündükleri de görülmektedir. Öğretmen adayları neden bu şekilde düşündüklerini uygulama öncesinde "bilim teknolojiyi kapsar ve teknoloji sayesinde ürün üretilir"; uygulama sonrasında ise "bilim araştırma sürecidir ve önce doğarak teknolojiyi geliştirir, teknoloji ise materyal üretme/sonuç ortaya koyma sürecidir" açıklamalarıyla ifade etmişlerdir.

Elde edilen bu sonuçların yanı sıra öğretmen adayları teknolojinin, bilimsel araştırmalarda yönlendirici olduğunu ve motivasyonu sağladığını; ayrıca uygulama öncesinde teknolojik araçların "araştırma-inceleme yapmayı kolaylaştırarak, yeni ürün oluşturmaya neden olduğunu", uygulama sonrasında ise "daha yeni araç üretmeye neden olduğunu" ve böylece bilime katkı sağladığını belirtmişlerdir. Sınıf içerisinde yapmış oldukları açıklamalarda da öğretmen adayları bilim ve teknolojideki gelişmelerin bireyi ve dolayısıyla da toplumu etkilediği; bununsa içinde yaşanılan çevreye yönelik olumlu ya da olumsuz etkilerinin olabileceğini ifade etmişlerdir. Turgut'un (2005) yapmış olduğu çalışmada ise öğretmen adayları "teknolojinin bilime araç-gereç temin ettiğini" belirtmişlerdir. Çınar'ın (2013) okulöncesi öğretmenleriyle yapmış olduğu araştırmada öğretmenler teknolojiyi, fenin bir uygulaması olarak görmekte ve teknolojinin kendine ait bilgi birikimine sahip olmadığını ve bu yüzden fene bağımlı olduğunu ifade etmişlerdir.

Öğretmen adayları uygulama öncesinde teknolojik tasarımların sıklıkla "insana-çevreye zararsız, maliyeti düşük ve kullanışlı olması, ayrıca ihtiyaçları karşılaması gerektiğini"; uygulama sonrasında ise "çevreye, topluma ve sağlığa zarar vermemesi, maliyetinin düşük olması ve yarar sağlaması" gerektiğini belirtmişlerdir. Çınar'ın (2013) yapmış olduğu araştırmada da öğretmenler teknolojik uygulamaların, toplum ve çevre değerlerini göz önüne alması 
gerektiğini belirtmişlerdir. Bir ülkedeki teknolojileri belirleyebilecek faktörleri ise öğretmen adayları uygulama öncesinde "iyi bir ekonomi, halkın ihtiyaçları, ülkenin kalkınma seviyesi, eğitim şartlarının iyi olması ve eğitimin önemsenmesi"; uygulama sonrasında ise "ekonomik durum, toplum, çevre, eğitim seviyesi, sağlığa zarar vermeme, ihtiyaç ve toplumun yararına olma" ifadeleri ile açıklamışlardır. Turgut'un (2005) yapmış olduğu araştırmada ise öğretmen adayları geliştirilen tasarımların "kullanışlı ve ekonomik olması gerektiğini" ve teknolojik gelişmenin "sosyo-ekonomik, siyasi ve politik faktörlere" bağımlı olduğunu düşündükleri tespit edilmiştir.

Bilim ve teknolojinin günlük yaşamımızın olmazsa olmazları haline geldiği günümüz dünyasında; bu alanda yaşanan gelişmelerin toplum ve çevre üzerindeki etkilerinin tartışılması, günlük yaşamımızdaki problemlerin çözümünde bilim ve teknolojinin nasıl kullanılacağı, bu konudaki farkındalığın nasıl artırılacağı, öğretim sürecinde bilim ve teknolojiden nasıl faydalanılacağı, bilim-teknoloji-toplum ilişkisini kurabilen bireylerin nasıl yetiştirileceği gibi pek çok soru halen gündemdedir. Bilgiye ulaşmanın, gerek akıllı telefonlar gerekse bilgisayarlar gibi pek çok farklı araç yardımıyla hızla kolaylaştığı günümüzde, bireylerin ilgisini çekebilecek ve günlük yaşamla birleştirilebilecek nitelikteki farklı materyallerin öğretim aracı olarak kullanılmasının oldukça işlevsel sonuçlar doğuracağı düşünülmektedir. Bilim kurgu filmler içeriğinde fen kavramlarıyla birlikte bilim, teknoloji, toplum ve çevre gibi pek çok konuyu da beraberinde işlemekte; bu bağlamda öğrenme ortamında öğretmenin rehberliğinde oldukça etkin bir şekilde kullanılabilecek bir materyal olarak nitelenebileceği görülmektedir.

Shaw ve Dybdahl'ın (2000) belirttiğine göre öğrenciler formal yollardan olduğu kadar informal yollardan da öğrenmekte ve bu iki tip öğrenme bazen öğretim programını desteklerken, bazense çatışabilmekte ve öğrencileri yanlış bilgilere maruz bırakabilmektedir. Informal yollardan biri olan bilim kurgu filmler literatürde de görüldüğü gibi öğrenme sürecine yönelik farklı pek çok katkı sağlamaktadır. Bu katkının ne düzeyde olacağı ve öğretimin nasıl şekillendirileceği gibi konular, süreci yönlendiren öğretmenlere önemli sorumluluklar yüklemektedir. Günlük yaşamdaki bilgiyi nasıl kullanacağını, yorumlayacağını ve bunu bilimsel açıdan nasıl açıklayabileceğini bilmeyen; bir öğretmen, geleceğin nesilleri olacak olan öğrencileri yetiştirme hususunda eksik kalacak ve çeşitli sorunlar yaşayacaktır. Bu bağlamda öğretmen yetiştiren kurumlara önemli görevler düşmektedir.

Her açıdan donanımlı bir bireyin yetiştirilmesi öğretmenin etkililiğine bağlıdır. Donanımlı bir şekilde mezun olan, mesleği süresince farklı hizmet içi öğretim programlarına katılan, mesleğini ve öğrencilerini severek görevini yapan bir öğretmen; öğrencilerini de aynı şekilde yetiştirecektir. Bu nedenle eğitim fakülteleri, yalnızca öğretmen mezun eden bir kurum olma kimliğinin yanı sıra; farklı becerileri de kazanmış, nitelikli öğretmenler mezun etmelidir. Bu bağlamda eğitim fakültelerinde görev yapan akademik personelin de farklı bilgi, beceri ve deneyimlere sahip olması; ayrıca öğretmen adaylarına deneyimlerini aktararak, benzeri deneyimleri onların da yaşaması için zemin hazırlamalıdır. Araştırma sonuçları doğrultusunda aşağıdaki öneriler getirilmiştir:

- Öğretim sürecinde gerek bilim kurgu gerekse farklı nitelikteki görsel materyallere daha fazla yer verilerek derse yönelik ilginin artırılması,

- Öğretim sürecinde kullanılabilecek farklı nitelikteki görsel medya araçlarına yer verilerek öğrencilerin gündelik yaşam ile feni bir araya getirmesi,

- Görsel medya araçlarının kullanımı sürecinde bilimsel bilginin elde edilmesi, veri toplama ve analiz etme, bilim insanının özellikleri, bilim-teknoloji-toplum ilişkisi, gündelik yaşamda bilimsel bilginin kullanılması gibi farklı fen ve teknoloji okuryazarlığının alt boyutlarının tartışılması, 
- Öğretim sürecinde teknolojiyi daha etkin kullanabilecek nitelikte ders planlarının tasarlanması önerilmektedir.

\section{KAYNAKÇA}

Acar, H. (2003). Fizik eğitiminde bilimkurgu hikayelerin kullanılması (Yayımlanmamış Yüksek lisans tezi). Marmara Üniversitesi, Eğitim Bilimleri Enstitüsü, Orta Öğretim Fen ve Matematik Alanları Eğitimi Anabilim Dalı, Fizik Öğretmenliği Bilim Dalı, İstanbul.

Akbaş, O. (2011). Bir öğrenme nesnesi olarak eğitsel kısa filmler: öğretmen adaylarının çektikleri eğitsel kısa filmler üzerine bir değerlendirme. Gazi Üniversitesi Endüstriyel Sanatlar Eğitim Fakültesi Dergisi. 27, 15-27.

Alvarez, J. L., Miller, P., Levy, J. vd. (2004). Journeys to the self: Using movie directors in the classroom. Journal of Management Education. 28(3), 335-355.

Aquinc, J. (1976). Science fiction as literature. National Education Association Publication. Washington, D. C.

Balbağ, M. Z., Yenilmez, K. vd. (2012). Matematik ve fen bilgisi öğretmen adaylarının bilimkurgu filmlerine yönelik görüşlerinin bazı değişkenler açısından incelenmesi. Eğitim ve Öğretim Araştırmaları Dergisi. 1(3), 232-241.

Barnett, M., Wagner, H. vd. (2006). The impact of science fiction film on student understanding of science. Journal of Science Education and Technology. 15(2), 179-191

Barnett, M., \& Kafka, A. (2007). Using science fiction movie scenes to support critical analysis of science. Journal of College Science Teaching, 36(4), 31-35.

Baş, T., \& Akturan, U. (2008). Nitel araştırma yöntemleri. Ankara: Seçkin Yayınevi.

Bixler, A. (2007). Teaching evoluation with the aid of science fiction. The American Biology Teacher. 69(6), 337-340.

Brake, M. \& Thornton, R. (2003). Science fiction in the classroom. Physics Education. 38(1), 3134.

Buluş Kırıkkaya, E., İşeri, Ş. vd. G. (2009). High school students' thoughts about science on television programmes. Procedia Social and Behavioral Sciences. 1, 921-926

Cavanaugh, T., \& Cavanaugh, C., (1996). Learning science with science fiction films. Paper presented at the Annual Meeting of the Florida Association of Science Teachers, 1996, October, Key West, FL.

Czerneda, J. E. (2006). Science fiction \& scientific literacy. The Science Teacher. 38-42.

Çınar, S. (2013). Okul öncesi öğretmenlerinin fen-teknoloji-toplum-çevre hakkındaki görüşleri. Eğitim ve Öğretim Araştırmaları Dergisi. 2(1), 349-363.

Çepni, S., Bacanak, A. vd. (2003). Fen eğitiminin amaçlarında değişen değerler: Fen-teknolojitoplum. Değerler Eğitimi Dergisi. 1 (4), 7-29.

Dark, M. L. (2005). Using Science Fiction Movies in Introductory Physics. The Physics Teacher. 43, 463-465.

Dubeck, L. W., Moshier, S. E. vd. (1993). Finding the facts in science fiction films. Science Teacher. 60(4), 46-48. 
Fife, E. (1999). Using science fiction to teach mainstream literature. Paper presented the Annual Meeting of the South Atlantic Modern Language Association, November 4-6, 1999, Atlanta, GA.

Kirby, D. A. (2003). Science consultants, fictional films, and scientific practice. Social Studies of Science. 33(2), 231-268

Laprise, S., \& Winrich, C. (2010). The impact of science fiction films on student interest in science. Journal of College Science Teaching. 40(2), 45-49

Lin, K., Tsai, F., Chien, H. vd. (2013). Effects of a science fiction film on the technological creativity of middle school students. Eurasia Journal of Mathematics, Science \& Technology Education. 9(2), 191-200

Lundquist, C. A. (2012). The science and fiction of Robert L. Forward. Physics Procedia. 38, 109 $-115$

MEB (Milli Eğitim Bakanlığı). (2006). Talim ve Terbiye Kurulu Başkanlığı. Illköğretim Fen ve Teknoloji Dersi (6, 7, 8.Sınıflar) Öğretim Programı, Ankara.

MEB (Milli Eğitim Bakanlığı). (2013a). Talim ve Terbiye Kurulu Başkanlığı. Illköğretim Kurumları Fen Bilimleri Dersi Öğretim Programı (3, 4, 5, 6, 7, 8. Sınıflar) Öğretim Programı, Ankara.

MEB (Millî Eğitim Bakanlığı) Yenilik ve Eğitim Teknolojileri Genel Müdürlüğü, (2013b). PISA 2012 Ulusal ön raporu, Ankara.

Miles, M. B., \& Huberman, A. M. (1994). Qualitative data analysis (2nd Edition). Thousand Oaks: Sage Publications.

Ongel Erdal, S., Sönmez, D. vd. (2004). Science fiction movies as a tool for revealing students' knowledge and alternative conceptions. Paper Presented at NARST 2004, April 1-3, 2004, Vancouver, CANADA.

Ontell, V. (1997). Science fiction: popular culture as reading and learning motivation. Paper presented at the Joint Popular Culture Association/American Culture Association Meetings, March 26-29,1997, San Antonio.

Özdemir, O. U. (2010). Fen ve teknoloji öğretmen adaylarının fen okuryazarlığının durumu. Türk Fen Eğitimi Dergisi. 7(3), 42-56.

Powell, L. (2009). Science fiction or reality? International Review of Psychiatry. 21(3), 273-275

Rose, C. (2003). How to teach biology using the movie science of cloning people, resurrecting the dead, and combining flies and humans. Public Understanding Science. 12, 289-296

Seçkin Kapucu, M. (2014). Fen ve teknoloji dersinde görsel medya kullanımına yönelik fen bilgisi öğretmenlerin görüşleri. Pegem Eğitim ve Öğretim Dergisi. 4(2), 75-90.

Shaw, D. G. \& Dybdahl, C. (2000). Science and the popular media. Science activities: classroom projects and curriculum ideas. 37(2), 22-31

Sürmeli, H. (2012). Examination the effect of science fiction films on science education students' attitudes towards STS course. Procedia - Social and Behavioral Sciences. 47, 1012-1016.

Sürmeli, H. (2013). Fen ve matematik eğitiminde teknolojik pedagojik alan bilgisi temelli öğretim tasarımları. In T. Y. Yelken, H. S. Tokmak, S. Özgelen \& L. İncikabı. (Ed.), Bilim kurgu filmlerinin desteği ile TPAB temelli-fen teknoloji toplum dersi tasarımı (pp. 149164). Ankara: Anı Yayıncılık. 
Thier, H. (1985). Societal issues and concerns: A New Emphasis for Science Education. Science Education. 69(2), 255-262.

Toraman, S. \& Aydın, H. (2013). Öğretmen adaylarının fen-teknoloji-toplum- çevre ilişkilendirmelerine yönelik görüşleri. Bartın Üniversitesi Eğitim Fakültesi Dergisi. 2(2), 146-170

Turgut, H. (2005). Yapılandırmacı tasarım uygulamasının fen bilgisi öğretmen adaylarının bilimsel okuryazarlık yeterliklerinden "bilimin doğası" ve "bilim-toplum-teknoloji ilişkisi" boyutlarının gelişimine etkisi (Yayımlanmamış Doktora tezi). Yıldız Teknik Üniversitesi Sosyal Bilimler Enstitüsü, İstanbul.

Turgut, H. \& Fer, F. (2006). Fen bilgisi öğretmen adaylarının bilimsel okuryazarlık yeterliklerinin geliştirilmesinde sosyal yapılandırmacı öğretim tasarımı uygulamasının etkisi. Eğitim Bilimleri Dergisi: Marmara Üniversitesi Atatürk Eğitim Fakültesi. 24, 205-229

Uğraş, M., \& Cil, E. (2012). Fen bilgisi öğretmen adaylarının fen-teknoloji- toplum (FTT) hakkındaki görüşleri. X. Ulusal Fen Bilimleri ve Matematik Eğitimi Kongresi'nde sunulmuş bildiri. Niğde Üniversitesi, Eğitim Fakültesi, 27-30 Haziran 2012, Niğde. http://kongre.nigde.edu.tr/xufbmek/dosyalar/tam_metin/pdf/2483-30_05_201222_48_02.pdf adresinden edinilmiştir.

Weber, C. M., \& Silk, H. (2007). Movies and medicine: An elective using film to reflect on the patient, family, and illness. Family Medicine. 39(5), 317-319.

Yang, A. (2002). Science fiction in the EFL class. Language, Culture and Curriculum. 15(1), 50-60

Yazıcı, N. N., \& Altıparmak, M. (2010). Science fiction aided biotechnology instruction: effects of bioethics group discussions on achievement and attitudes. Procedia Social and Behavioral Sciences. 2, 4125-4129.

Yıldırım, A. \& Simsek, H. (2013). Sosyal bilimlerde nitel arastırma yontemleri. 9.baskı Ankara: Seckin Yayın. 
Ek 1: Bilim-Teknoloji-Toplum Anketi

\section{BILIM-TEKNOLOJI-TOPLUM ANKETI}

1) Sizce teknoloji nedir, mühendis kimdir kısaca açıklayınız. Teknolojiyi bilimden ayıran unsurlar nelerdir açıklayınız.

2) Sizce yeni geliştirilen teknolojik araçlar bilime ve bilimsel araştırmalara ciddi katkılar sağlayabilir mi? Cevabınız evet ise ne tür katkılar sağlayabileceğini bazı örneklerle açıklayınız?

3) Teknolojinin bilimsel araştırmalarda yönlendirici olma, motivasyon sağlama gibi rolleri olabilir mi? Cevabınız evet ise bazı örneklerle açıklayınız?

4) Teknolojik tasarımlar yardımıyla gündelik yaşantımızda karşılaştığımız bütün problemleri çözebilir miyiz? Bu konuda fikirlerinizi destekleyen bazı örnekler verebilir misiniz?

5) Teknolojik araçların gündelik hayata etkileri konusundaki düşüncelerinizi örneklerle açıklayınız.

6) Sizce en uygun mühendislik tasarımlarında hangi şartların sağlanmış olması gerekir kısaca açıklayınız.

7) Teknolojik sistemlerin, tasarımların başarısız olma ihtimalini tamamıla ortadan kaldırabilmek mümkün müdür açıklayınız.

8) Bir ülkede ya da toplumda geliştirilebilecek (örn: nükleer teknoloji, uzay teknolojisi vb.) teknolojileri belirleyen faktörler nelerdir örneklerle açıklayınız. 


\section{SUMMARY}

The PISA result of 2012 shows that Turkey's student rate in scientific literacy is above the OECD average (MEB, 2013b). This result puts forth that the education process has some problems despite the reform movements and that the problem should be addressed from different angles. Acar (2003), on the other hand, stated that the students learn the scientific facts and principles from extracurricular sources as much as the course content. According to Shaw and Dybdahl (2000), extracurricular sources are categorized into two; visual and written media means. As one of the visual media means, the films have become a part of the social life and are used not only for entertainment but also for educational and scientific research purposes, as suggested by Akbaş (2011). In this regard, it is thought that the science fiction films as a separate type of films could be effectively used as a means in the education process. The aim of the research is to shed light on the impact of science fiction films on the prospective science teachers' views regarding science-technology-society.

The research has been conducted in the form of "case study" from qualitative research designs in the spring term of 2012-2013 academic year. The study group of the study is consisted of 20 prospective teachers studying at the second grade in primary science education department of a university in Istanbul. The prospective teachers who participated in the research were selected on voluntary basis from among the prospective teachers taking the course "sciences and society", which was taught by the researcher.

The research was conducted in two steps, data collection and application. The duration of application of the research was 5 weeks and 10 science fiction films chosen by the researcher were watched in this process. Careful attention has been paid to include different science concepts and areas (physics, chemistry, biology) in the selection of films. Also, another focus in the selection of films has been on different technological tools chosen in accordance with the topic of the film and used in this process.

The research data were collected with "document analysis". The documents of the research are consisted of "Science-Technology-Society Survey" (Turgut, 2005) containing 8 questions and "video records" obtained from in-class discussions. The data collected from Science-Technology-Society were assessed through content analysis. Accordingly, the questions were coded firstly and after that the themes were formed and presented in tables. The data collected from video records were used in order to support the data collected from the survey after being written down by the researcher and for this reason no detailed analysis was conducted in this process. For the purpose of ensuring the validity and reliability of the qualitative data obtained from the research, diversity in researcher and data was applied. The data obtained from the survey were coded by another researcher expert in science education and the consistency rate between the two coding was determined with compliance percentage formula by Miles and Huberman (1994), and it has been indicated that the research was reliable if the consistency between the two coding was above $80 \%$. The compliance percentage between the researchers was revealed to be $85 \%$ in the research. In this respect, it is thought that the research analysis has been reliable.

It has been observed in the research that the views of prospective teachers on sciencetechnology-society before and after the research application had correct qualities. It has also been revealed in Özdemir's research (2010) that prospective science and technology teachers understand the relation among science-technology-society. It is also thought that the views of prospective teachers differed after the application in terms of quantity and quality and that science fiction films contributed positively to the related views. In today's world where science and technology have become a necessity in our daily life, many questions such as the impacts of the developments taking place in these fields on the society and environment, how to use science and technology in solving the problems of our daily life, how to raise awareness in this respect, how to benefit from science and technology in the education process, and how to raise individuals who can establish the science-technology-society relation are still on the agenda. In this era when access to knowledge gets rapidly easier thanks to many instruments such as smart phones and computers, it is thought that the use of different materials, which can draw individuals' attention and can be related to daily life, as an education tool could bring about quite functional results. 